\title{
Mucopolysaccharidosis at play?
}

\author{
Agata Fiumara ${ }^{1}$
}

Received: 15 September 2017 / Accepted: 10 October 2017 / Published online: 28 November 2017

(c) European Society of Human Genetics 2018

The eyes of clinical geneticists see more and differently from ordinary eyes trained as they have been to probe analytically even the most subtle aspects of the human physiognomy and overall appearance. Collections of ancient cultural-artistic artefacts offer an excellent opportunity to search for representations of human disease or developmental disorder. Best known are achondroplasia in Egyptian art, cyclopia, sirenomelia, hermaphroditism, conjoint twinning, etc. in Greek sculpture. This includes the many remarkable terracotta masks and figurines discovered in the necropolis of Lipari, one of the Aeolian islands of Italy, near Sicily. Dating to the 4th and 3rd century BCE, these artefacts are an important aspect of Greek theater and funerary art involving the cult of Dionysos in Magna Graecia. (Figs. 1 and 2)

Dionysos was the god of wine, theater, and supernatural bliss. Thus, a strong correlation between his cult and funerary art is evident in these tombs with small masks portraying characters of Greek tragedy and comedy by Sophocles, Euripides, and Aristophanes, and representations of what the actors wore during performances. Some portrayed specific characters, for example, young hero, old man, Hecuba, Paris, Helen, etc.

The change in style to the "New Comedy" taking its inspiration from daily life, began with Menander (342-290 BCE) at the beginning of the 3rd century and is remarkably well represented in the small Lipari terracottas reflecting moods and postures [1].

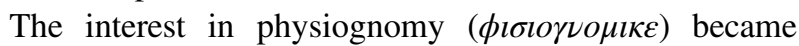
strong during the 4th century BCE in various philosophical schools variably influenced by medicine. Hippocratic doctrine taught that normal or abnormal human function was due to perfect balance or an imbalance of the four essential humors (black or yellow bile, cerebral fluid, and blood), and

Agata Fiumara

agafiu@virgilio.it

1 Regional Referral Centre for Inborn Errors Metabolism, Pediatric Clinic, Department of Clinical and Experimental Medicine, University of Catania, Via Santa Sofia 78, 95123 Catania, Italy that the specific mix in each individual was responsible for its temperament and disposition to act, the former reflected in the person's appearance. This view of life and the relationship between mood and appearance was reflected in fashioning the mask, portraying its character and bringing out anything unusual, or peculiar in facial configuration.

In Lipari's tomb \#1613 [2] a group of masks was found and attributed to characters in the comedy of Aristophanes called "Ecclesiauze" (Assembly women). One of these masks is catalogued as "African slave" for the strongly modeled traits of prognathism, prominent supraorbital ridges, large nose with depressed nasal bridge, thick lips, short neck and thick curly hair [1]. This facial appearance strongly suggests a mucopolysaccharidosis (MPS). Also, a small statue labeled a "prostatic old man" shows a similar facial appearance and prominent abdomen, genua valga and an odd posture suggestive of visceromegaly and the skeletal dysplasia seen in a MPS such as Hurler or Hunter syndrome.

These disorders due to deficiency of specific lysosomal enzymes are clinically characterized by progressive and disabling manifestations and, despite their heterogeneity, share several key manifestations such as "coarse" facial features, visceromegaly, joint stiffness and dysostosis multiplex, corneal clouding, hernias, recurrent upper respiratory tract infections, heart valve disease and carpal tunnel syndrome [3]. Lack of awareness of MPS, combined with variability in symptoms makes the diagnosis difficult, but the typical progressively worsening phenotype should arouse clinical suspicion, and an experienced physician might make the diagnosis at first sight.

The Lipari's masks suggest that MPS phenotypes were recognized in the past and generically considered abnormal, thus transformed into art.

Acknowledgements The Author wishes to thank Prof. John Opitz for his friendly advices and revision of the manuscript. Dr AnnaMaria Mastelloni, Director of the Lipari Bernabò Brea Museum, for historical information and permission to use images from the Museum. The McGraw-Hill Companies, Inc. for giving permission to use the MPS patient photo taken from Neufeld EF, Muenzer J. The Mucopolisaccharidoses. In "The metabolic and molecular bases of inherited 
Fig. 1 a Child with Hurler syndrome (from Beaudet, Arthur and Valle, David: The Metabolic Bases of Inherited Disease Figure 78-6 on Page 2472 with permission); b "Prostatic old man"; c "African slave" (enlarged in Fig. 2)

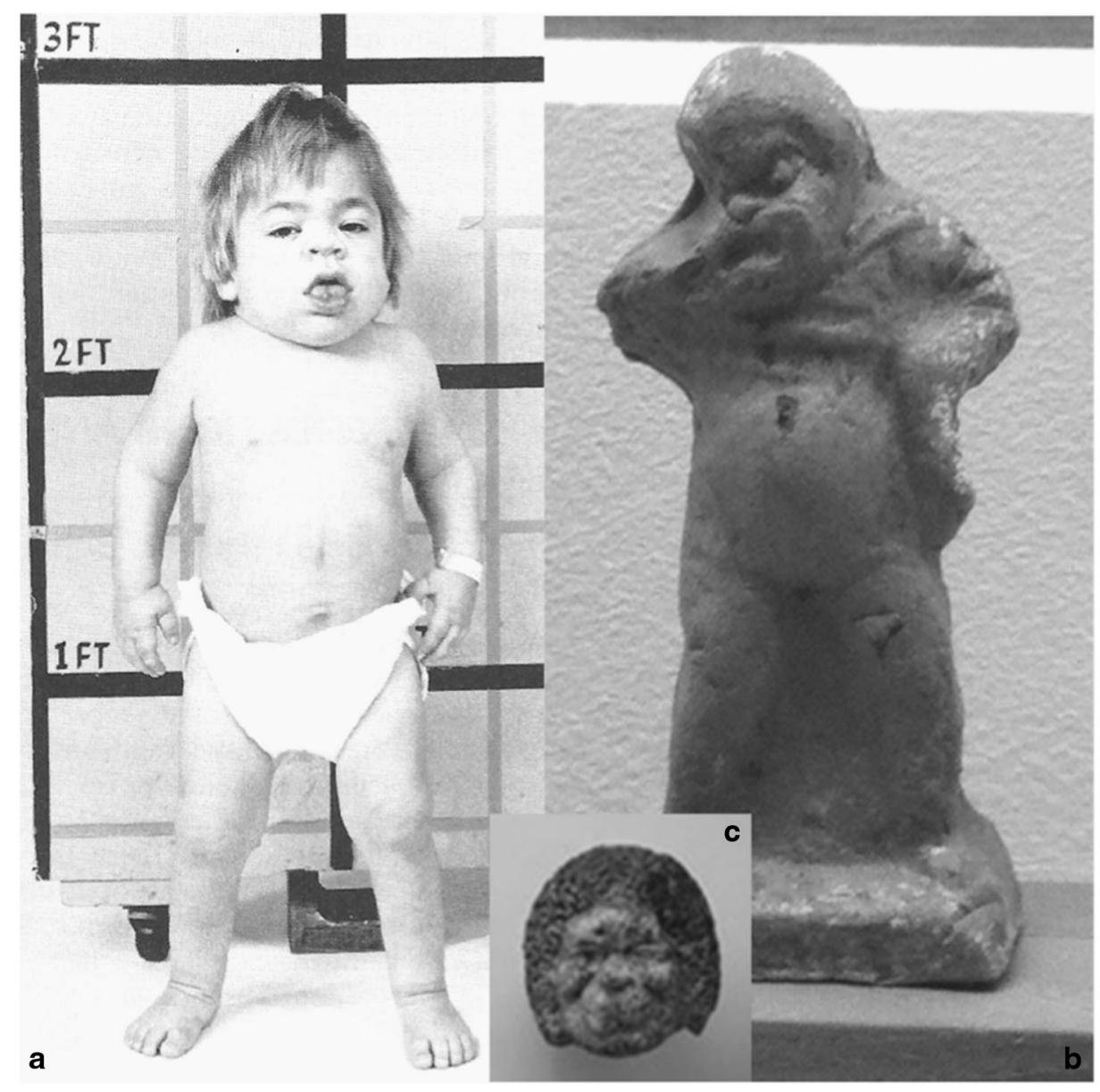

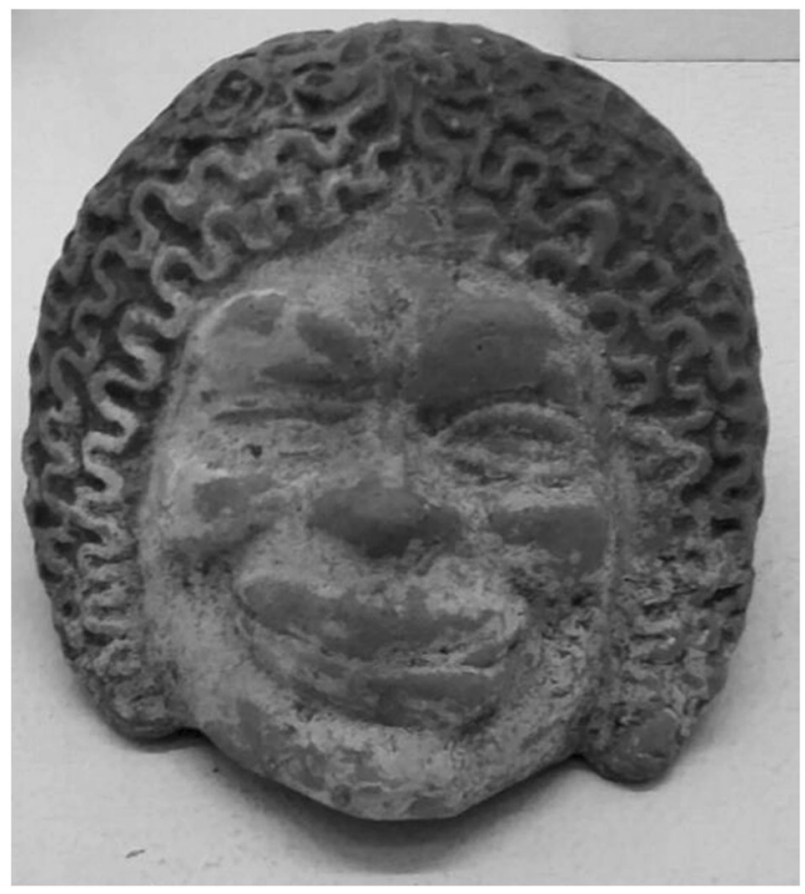

Fig. 2 "African slave" Fig. 1c enlarged disease", Scriver CR, Beaudet AL, Sly WS, Valle D eds; 7/e, McGraw Hill, Ch 78, pg 2465-2494.

\section{Compliance with ethical standards}

Conflict of interest The author declares no conflict of interest.

\section{References}

1. Bernabò Brea L, Menandro e il teatro greco nelle terrecotte Liparesi, Genova 1981, p. 56

2. http://www.regione.sicilia.it/beniculturali/museolipari/pagina.asp? Idsez3 = 2 Maschere relative a personaggi della commedia Le Ecclesiazuse di Aristofane. Tomba 1613 (IV sec. a.C.)

3. Neufeld EF, Muenzer J The Mucopolisaccharidoses. In "The metabolic and molecular bases of inherited disease", Scriver CR, Beaudet AL, Sly WS, Valle D eds; 7/e, McGraw Hill, Ch 78, pg 2465-2494 